\title{
OPTIMIZATION OF TOURISM ORGANIZING IN THEKELAN, BATUR VILLAGE, GETASAN DISTRICT, SEMARANG REGENCY
}

\author{
${ }^{1}$ Kuat Waluyo Jati, ${ }^{2}$ Agus Wahyudin, ${ }^{3}$ Bestari Dwi Handayani \\ ${ }^{1,2,3}$ Universitas Negeri Semarang
}

\section{ARTICLE INFO}

Article History:

Received February, 11, 2021

Accepted June, 17, 2021

Available June, 302021

\section{Keywords:}

Village Tourism;

Tourism Management;

Thekelan Village

\begin{abstract}
Dusun Thekelan di Desa Batur Kecamatan Getasan Kabupaten Semarang memiliki keunggulan sebagai desa wisata alam, tepatnya alam pegunungan. Letaknya yang berada di lereng Gunung Merbabu menjadikan Desa Thekelan menjadi salah satu jalur pendakian, bahkan jalur tertua untuk mencapai ke puncak Gunung Merbabu. Jalur pendakian sampai saat ini dikelola oleh karang taruna setempat yang kemudian menjadi salah satu sumber pendapatan bagi desa. Namun pengelolaan tersebut belum dimaksimalkan dan belum terintegrasi dengan Badan Usaha Milik Desa (BUMDes) Desa Batur sehingga kebermanfaatan masih sangat terbatas. Tujuan pengabdian ini adalah untuk meningkatkan kesadaran pengelola jalur pendakian dan masyarakat bahwa pengorganisasian yang tepat dapat meningkatkan kualitas dari pelayanan yang diberikan dan berujung pada keuntungan yang lebih baik. Pengorganisasian yang lebih baik dapat memperluas bisnis dalam pengelolaan jalur wisata dan menunjang BUMDes yang telah berdiri. Pelaksanaan pengabdian dilakukan dengan metode ceramah, tanya jawab, diskusi, dan pendampingan. Langkah strategis yang dilakukan adalah dengan: 1) memberi wawasan tentang pengorganisasian wisata, 2) memberi wawasan tentang keuntungan pengelolaan wisata dalam wadah BUMDes, 3) diskusi dan tanya jawab dengan memberikan kesempatan kepada masyarakat dan perangkat dusun, 4) pendampingan kepada masyarakat, dan 5) evaluasi hasil pengabdian yang telah dilakukan. Kegiatan pengabdian dilakukan berdasar kesepakatan dengan warga sasaran pada bulan Oktober 2020, Warga merasa memperoleh informasi lebih dalam terkait dengan pengelolaan pariwisata dan pengembangannya serta kebermanfaatan dengan melakukan sinkronisasi bisnis dengan BUMDes yang telah berdiri di Desa Bathur.
\end{abstract}

Thekelan Village in Batur Village, Getasan District, Semarang Regency has the advantage as a nature tourism village, precisely mountainous nature. Its location on the slopes of Mount Merbabu makes Thekelan Village one of the hiking trails, even the oldest path to reach to the top of Mount Merbabu. The hiking trail until now was managed by a local taruna reef which later became one of the sources of income for the village. However, the management has not been maximized and has not been integrated with the Village Owned Enterprises (BUMDes) batur village so the benefits are still very limited. The purpose of this service is to raise awareness of hiking trail managers and the community that proper organizing can improve the quality of the services provided and lead to better profits. Better organizing can expand the business in the management of tourist routes and support BUMDes that have been established. The implementation of devotion is done by methods of lectures, Q\&A, discussions, and mentoring. Strategic steps taken are by: 1) giving insight into the organization of tourism, 2) giving insight into the benefits of tourism management in BUMDes containers, 3) discussions and Q\&A by providing opportunities to the community and hamlet devices, 4) mentoring to the community, and 5) evaluation of the results of devotion that has been done. The service activities are carried out based on an agreement with the target citizens in October 2020, residents feel more information related to the management of tourism and its development and benefits by synchronizing business with BUMDes that have been established in Bathur Village.

\section{Address: L Building, Campus Sekaran, Gunungpati, Semarang,} Indonesia, 50229

Correspondent Address:

Universitas Negeri Semarang

Email: kuatwaluyojati.unnes@mail.unnes.ac.id 


\section{INTRODUCTION}

Semarang is one of the regencies in Central Java Province with the name Ungaran Capital. It is bordered by Semarang city to the north; Demak and Grobogan districts in the east; Boyolali County to the east and south; Salatiga City in the middle of Semarang Regency; Magelang, Temanggung, and Kendal districts in the west. Ungaran, the capital of this district, is right bordered by Semarang City. The eastern part of the district is a plateau and hills. The great river that flows is the Tuntang River. In the western part of the region in the form of mountains, with the peak of Mount Ungaran (2,050 meters) on the border with Kendal Regency, and Mount Merbabu (3,141 meters) in the southwest. Portrait of semarang regency, making it has various tourist destinations, one of which is related to nature.

Getasan subdistrict is a sub-district in Semarang Regency, Central Java, Indonesia located between Salatiga City and Magelang Regency. This sub-district is located on the slopes of Mount Merbabu. Getasan is directly adjacent to Ngablak District of Magelang District to the west, Banyubiru District to the north, Kec landmark on the south, and with Salatiga City to the east. Getasan subdistrict with the topography of mountainous areas. Distance from Getasan Subdistrict to Semarang Regency Capital is $37 \mathrm{Km}$.

Getasan sub-district consists of ten villages, namely Getasan Village, Kopeng Village, Batur Village, Tajuk Village, Ngrawan Village, Sumogawe Village, Polobugo Village, Tolokan Village, Jetak Village, and Samirono Village. Batur Village is located in Getasan District, Semarang Regency. Batur village has an area of about 1,087.73 ha, located at an altitude of $1,350 \mathrm{~m}$ above sea level with a slope-shaped topography and an average temperature of $300 \mathrm{C}$. The soil conditions in Batur Village are quite fertile so it is suitable for agriculture, especially horticulture and the average rainfall is $2,500 \mathrm{~mm} /$ year. There are 19 hamlets in Batur Village, namely Thekelan, Seloduwur, Nglelo, Tawang, Batur Kidul, Batur Wetan, Gondang, Dukuh, Selongisor, Kaliduren, Madu, Ngiringin, Kalitengah, Sanggar, Diwak, Senden, Rejosari, Wonosari, and Krangkeng. Batur Village has 19 Rukun Warga (RW) and 55 Rukun Tetangga (RT). The location of Thekelan Hamlet can be seen in figure 1 .

Thekelan village is one of the hamlets of Batur Village which has an altitude of 1,600 meters above sea level. This hamlet has tremendous natural tourism potential. One of the famous supporters of the tourist attraction is the climbing path of Mount Merbabu and this path is the oldest path to mount Merbabu. This hiking trail is managed by the youth of the hamlet through taruna coral. In addition, the community also makes their homes as a place to stay for tourists or climbers.

Thekelan village in addition to having a very beautiful nature, also has excellent community values. The profile of the villagers is diverse in embracing religions, such as Islam, Hinduism, and Christianity. Diversity in religion has long been a longstanding but never a problem that causes strife. Thekalan village is even considered as an exemplary village for the tolerance of its people (Tribunjateng.com, 2019). Thekelan Hamlet has tourism advantages that can be the flagship of Semarang Regency. Some forms of tourism that can be featured are arts and climbing tours.

The people of Dusun Thekelan still preserve the culture of previous generations, such as art. Various arts are still preserved such as ketoprak, prajuritan dance, gambyong dance, and warok. Temporary art flourishes are barongsai and drumblek. Tour the existing hiking trails such as mountain libraries, camp areas, waterfalls, and downhill bikes. The number of tourist attractions that should be able to advance hamlets, villages, subdistricts, even Semarang Regency.

Figure 1.

Map of Thekelan Hamlet

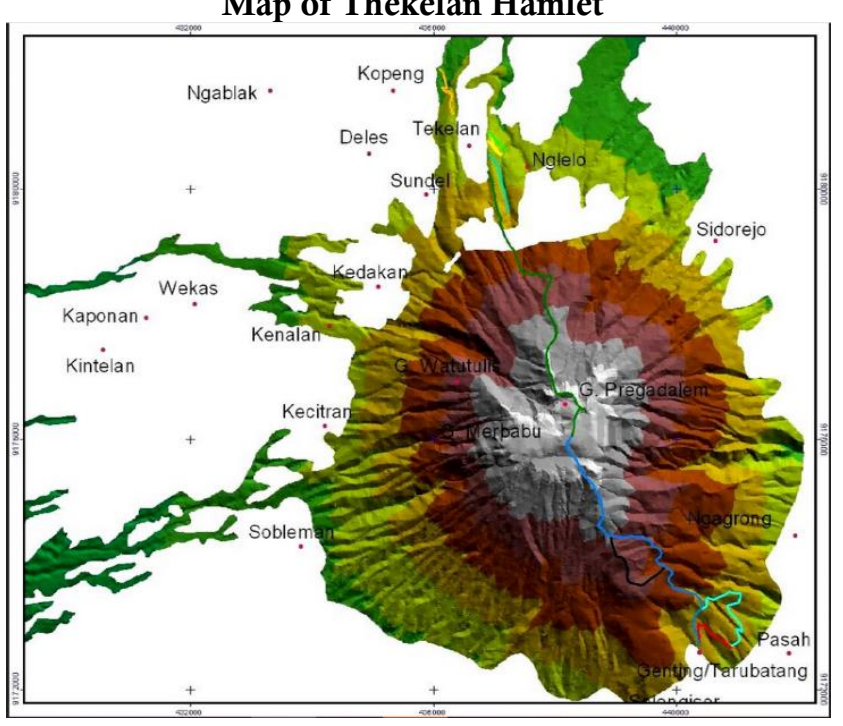

Indonesia's national development is now focused on human beings as its center (Kartasasmita, 2001). The community and the government must move together so that the expected development can be carried out properly. Government agencies must be supervisors, directors, and guidance providers of the development carried out. Development is expected to improve the welfare and living standards of the community, thus the community becomes the subject of development and the key to success is to empower the community.

Community empowerment is an effort to increase the ability and potential in a society to be able to survive and develop itself independently in the social, economic, cultural fields (Widjaja, 2003). Community empowerment must be able to reach rural communities and this is in line with the government's efforts to 
encourage villages to be independent. This is expected to improve the welfare of rural communities. The government has done many ways to make the village have original income. Law No. 6 of 2014 presents village-based economic institutions named Village Owned Enterprises (BUMDES). In Permendes PDTT No. 4 of 2015 mentioned that the objectives of BUMDes established include: (a) improving the village economy; (b) optimize village assets to benefit the welfare of the village; (c) improve community efforts in managing the economic potential of the village.

The people of Dusun Thekelan need to be given a motivation and a view to optimize integrated management of the advantages of tourism. Optimization of tourism management can combine various groups of managers to be able to synergize to provide better tourism services. This activity is expected to make Thekelan Hamlet more advanced and contribute to the success of the existence of BUMDes Batur Village.

Thekelan hamlet is a hamlet that has advantages in the natural tourism sector and the value of its people. The existing nature tourism is supported by the oldest climbing path to climb mount Merbabu. So people are very familiar how to do climbing and about the mountains. The value of the community held is also very good to be exemplified, differences in beliefs do not make the community conflict with each other. Differences in existing beliefs make the community more accentuating unity and this has been recognized by the wider community.

Various tourism potentials have, some have been managed by tour conscious groups. The group that has done the management is taruna coral that manages the climbing path to Mount Merbabu. However, other climbing related matters are still managed directly by the community individually so it still does not provide benefits for the hamlet institutionally, such as lodging for climbers in the homes of residents but not managed specifically by tourist conscious groups in the hamlet.

The arts and values of Thekelan Village people are less promoted to attract more tourists. The promotion is supposed to attract groups of tourists other than those who want to make the climb to Mount Merbabu. Any particular event that will later display art, such as ketoprak, warog, or others must be managed by a certain group and facilitate various needs that can support the comfort of tourists to come. If coordination can be done well, it could be that non-enslaved tourists can be interested in climbing Mount Merbabu.

The results of the interview with the head of Dusun Thekelan revealed that so far tourism management is still done independently. Government involvement has been largely in the realm of ensuring existing forests can always be sustainable and not looted. However, for the development of the tourism sector is still lacking. The community should be able to manage tourism more optimally so that it can integrate all the advantages owned by the hamlet to advance its community.

Dusun Thekelan has also worked with PT Indofood to provide agricultural products such as potatoes for their products. The potatoes that are expected to be purchased by PT Indofood have a certain size and weight. If the potatoes are not suitable then it will not be purchased by PT Indofood. The potatoes produced by Dusun Thekelan have excellent results, even many of which are larger than required. This causes too large potatoes cannot be given to PT Indofood and become unused goods. The community needs to get training to process the potatoes and then integrated with the management of village tourism, both for climbing and when the event that displays art.

BUMDes in Batur Village has also been operating as is. This according to residents is due to the lack of community support for the existence of BUMDes. BUMDes are also still considered to have not provided tangible benefits for the villagers. This kind of thinking becomes a bad thing because the existence of a BUMDes should be rooted in the superiority of what the supporters have, one of which is the superiority of each community / hamlet of the village.

Based on the formulation of the problem presented, it is necessary to do community service about optimizing the organization of tourism Thekel Hamlet to improve the business of Batur Village Owned Enterprises Getasan District Semarang. Based on the identification, the following problems are formulated.

1. How to optimize the organization of tourism conscious groups in Dusun Thekelan to support Dusun and BUM Desa Batur?

2. How does the contribution result from optimizing the organization of tourism conscious groups in Dusun Thekelan to support Dusun and BUM Batur Village?

\section{METHOD}

The community in Thekelan Village has problems in terms of tourism management there. Tourism management is still not well coordinated between tourism sectors. Thekelan village is already very famous in semarang regency as one of the interesting tourist areas from the natural side and its people. This shows tremendous potential when managed to the fullest. However, because it is not managed by integrated tourism gives the impression of Thekelan Hamlet is managed separately by certain groups.

The most prominent group is the taruna reef that manages the hiking trails. The trail is the oldest route to 
the top of Mount Merbabu. This trail is well known among climbers, especially in Indonesia. The community is mostly just paying more attention to this part. Other parts such as about art inherited by the ancestors, agricultural products that can be processed into typical food less get more health from the surrounding community. Management that integrates all these parts can improve the quality of tourism in Thekelan Hamlet.

Villages as a buffer of life are required to be independent in various sectors, such as social, cultural, and economic (Undang-Undang Republik Indonesia Nomor 6 Tahun 2014 Tentang Desa, 2014). The village currently has autonomous authority in management, such as planning, finance, and public services. The existence of such autonomy makes the village no longer just waiting for the instructions of the upper government, but can initiate. This initiation makes village development more dynamic, fast, and precise. The concept of entrepreneurial village has been widely mentioned and is a concern of many parties including other countries, countries such as Japan and Thailand even carry out a strategy for each village to produce one product (Kusuma \& Purnamasari, 2016).

A good village and able to manage all the potentials it has will be able to improve the standard of living of its people. Such villages certainly involve various elements, one of which is the support of the community in each village supporter, such as hamlets. Hamlets that are able to move each element will be able to generate strength to support the steps of the village, one of which is to support BUMDes work program. Thus, Dusun should be able to optimally run all the potentials that have, in this case is the integration of tourism management in Thekalan. Troubleshooting framework described figure 2 .

This community service is directed to the community and village devices, in Thekelan, Batur Village, Getasan District, Semarang Regency. Discussion, socialization, and training become problem solving models conducted by service people. The community in Thekelan is expected to be able to optimize the management of tourism and the village equipment is able to facilitate the integration of each group of tourism managers. The service team conducted activities at the place of service three times with the following details:

Identify the problem:

Results obtained:
1. Initial coordination, implemented in March 2020. In this activity, the community service team coordinated with the Head of Thekelan Sub-Village regarding the management of tourism that has been conducted.

2. The implementation of the service, the community service team will come to Tehekelan Hamlet to conduct socialization, mentoring, and training to raise public awareness of the potential of their villages and the integration of tourism management. Periodic monitoring and mentoring.

3. This activity is carried out after the implementation of the activity is completed. This is done to provide assistance if the community in Thekelan Hamlet faces difficulties in implementing the results of service and optimization of tourism management.

The realization of the implementation of the service model is to provide material related to the optimization of tourism management in accordance with standards. This is done because looking at the general conditions in the location, tourism management has not been integrated between tourism fields. Hopefully with this service the Thekelan community can optimally manage the tourism sector owned.

\section{RESULTS AND DISCUSSIONS}

The dedication activities began with a meeting between the dedication team and the Head of Thekelan, Batur Village. This is done to map the detailed needs of the people of Thekelan about organizing climbing tours and natural attractions in the hamlet. Presence is done in advance for the device of hamlets and villages as well as the responsibility of activities so that the devotional activities can take place properly.

Figure 2.

Troubleshooting framework

1. Vagueness of duties and authorities of tourism management groups,

2. Lack of managerial ability in tourism management,

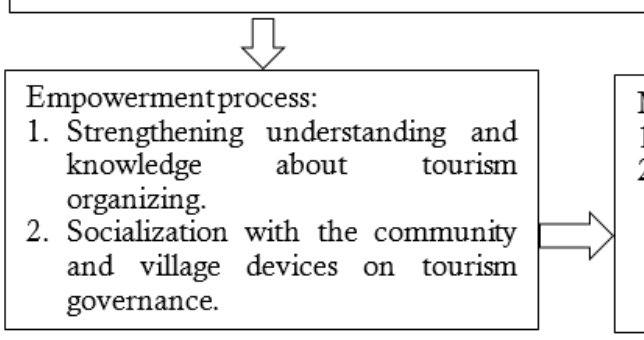
governance.
Mentoring process:

1. Simulation of tourism organizing.

2. To be an intermediary in establishing cooperation with local governments and related agencies in the efforts to develop pariwsata.
1. The community and tourism management groups gain strengthening, understanding and knowledge about tourism management.

2. The community and tourism management groups are able to apply the understanding and knowledge of tourism organizing in the management and development of Tourism Of Dusun Thekalan.

3. Thekelan Village Tourism is managed with the right organization, good, and correct. 
The service activity can be carried out on Friday, October 2, 2020 at the meeting hall of the residents of Thekelan, Village Batur District Getasan Semarang. Several devices of Batur Village and Thekelan Hamlet along with residents who manage tourism attended this devotional activity. The service is carried out in order to provide information and inputs related to the organization of tourism more efficiently and interestedly with village-owned enterprises (BUMDes). At the time of the interaction took place quite intensely, the participants were enthusiastic enough to discuss more related to what the resource person delivered. Tourism managers along with village and village devices give high attention so that tourism activities run well but can still be maintained forest nature in Thekelan Hamlet.

Figure 3.

Service Participants Listen to Exposure

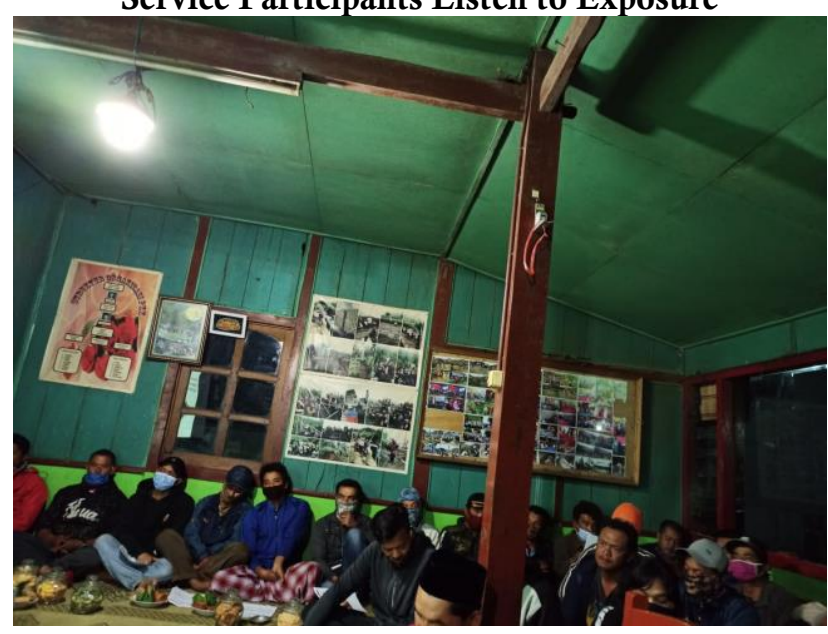

Figure 4.

Head of Thekelan Village Recorded The Answer to the Discussion Result

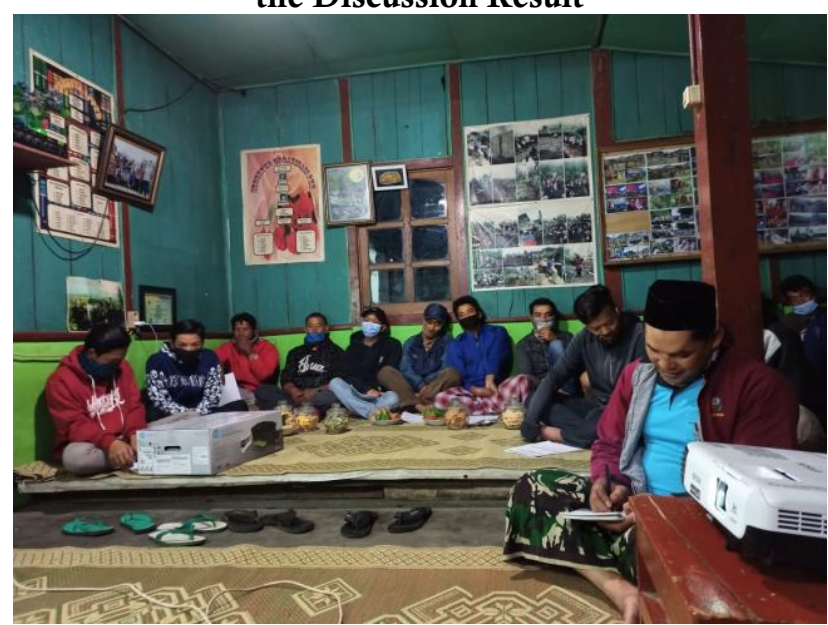

The residents of Thekelan Village want that managed tourism can grow bigger and provide better economic benefits to residents where tourist sites are located. The problem faced by residents is that bumdes are not optimally in sync with tourism activities in Thekelan Hamlet. Thekelan village which is one of the climbing paths of Mount Merbabu has tremendous natural potential. Natural potential in addition to the beauty of forests and hiking trails that attract tourists, many things that can be done by citizens in fact in doing entrepreneurship as a chain of services and tourist goods mountaineering. If the chain of business climbing the mountain can be run of course the economic benefits for the citizens will be greater.

Figure 5.

Photos During Exposure to Tourism Synchronicated and BUMDes

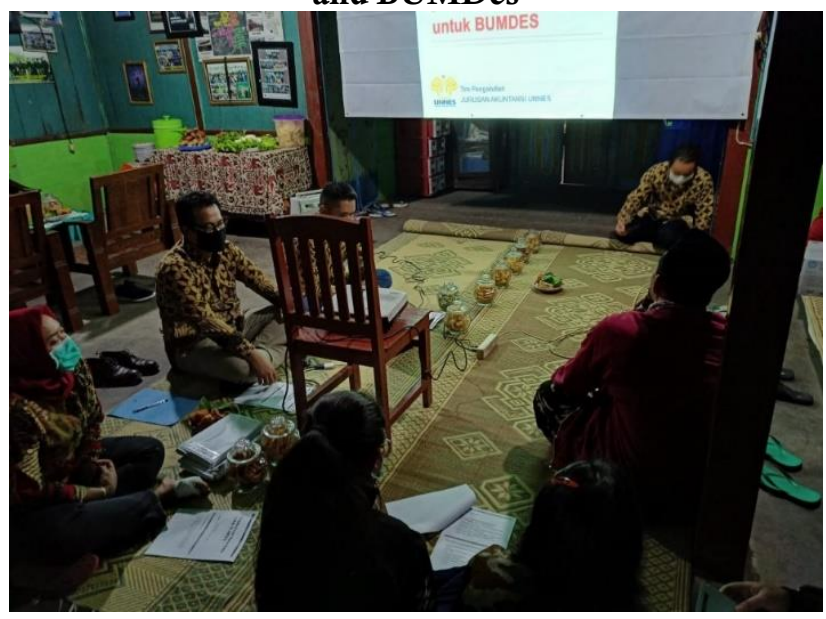

The results of the exposure and discussion between the service team and the service participants provide some changes in conditions that can be seen in table 1.

Table 1. Conditions Before and After Service Performed

\begin{tabular}{|c|c|c|c|}
\hline No & Elements & Pre-service & Post-service \\
\hline 1 & $\begin{array}{l}\text { Knowledge of } \\
\text { tourism } \\
\text { organizing }\end{array}$ & $\begin{array}{l}\text { Not yet in-depth } \\
\text { knowledge of } \\
\text { tourism } \\
\text { organizing, } \\
\text { which is } \\
\text { recommended to } \\
\text { be developed. }\end{array}$ & $\begin{array}{l}\text { People feel more } \\
\text { knowledge about } \\
\text { organizing } \\
\text { potential tourism. }\end{array}$ \\
\hline 2 & $\begin{array}{l}\text { Optimization of } \\
\text { tourism } \\
\text { organizing }\end{array}$ & $\begin{array}{l}\text { The community } \\
\text { and tourism } \\
\text { conscious groups } \\
\text { have not } \\
\text { organized well } \\
\text { for the tourism } \\
\text { owned }\end{array}$ & $\begin{array}{l}\text { The community } \\
\text { understands the } \\
\text { steps that can be } \\
\text { taken to realize } \\
\text { and develop the } \\
\text { organization of } \\
\text { tourism with } \\
\text { human resources } \\
\text { based, so as to } \\
\text { create good and } \\
\text { correct tourism } \\
\text { governance in } \\
\text { accordance with } \\
\text { tourism } \\
\text { management } \\
\text { standards and in } \\
\text { sync with } \\
\text { BUMDes Batur }\end{array}$ \\
\hline
\end{tabular}

The residents of Thekelan Village Batur District Getasan Semarang district as a participant of the service claimed to be helped and have a broader insight and views on how to increase tourism in the climbing path of Mount Merbabu. In addition, they are increasingly eager to create a chain of services and goods on the hiking trail by synchronizing activities on existing 
BUMDes. This is important to do because BUMDes will be a place of management and direction related to services or goods produced by the residents of Thekelan Hamlet

\section{CONCLUSION}

The dedication performed by the service team is able to provide information and insights to the residents of Thekelan Hamlet related to the governance of a tourist attraction hamlet. Devotion gives encouragement to the residents of Thekelan Hamlet to the spirit of finding a form of economic chain in terms of providing services or goods that can be produced by residents who live in the climbing path of Mount Merbabu. Devotion provides thought assistance on how Dusun Thekelan can synchronize economic actions related to the provision of services and goods with BUMDes Batur District Getasan Semarang so as to provide greater economic benefits.

Advice that can be given related to community service that has been done is done continuous service to the residents of Thekelan Hamlet in terms of extracting creative ideas about the provision of services or goods related to climbing Mount Merbabu. Conducted assistance related to the establishment of governance of natural tourism organizing Thekelan Hamlet and synchronicity with BUMDes Batur District Getasan Semarang District.

\section{REFERENCES}

Kartasasmita, G. (2001). Pembangunan untuk Rakyat: Memadukan Pertumbuhan dan Pemerataan. Pustaka CIDESINDO.

Kusuma, G. H., \& Purnamasari, N. (2016). BUMDES: Kewirausahaan Sosial yang Berkelanjutan (Analisis Potensi dan Permasalahan yang dihadapi Badan Usaha Milik Desa di Desa Ponjong, Desa Bleberan, dan Desa Sumbermulyo). Yayasan Penabulu.

Tribunjateng.com. (2019). Dusun Thekelan: Keindahan dan Toleransi di Kaki Gunung Merbabu.

Undang-Undang Republik Indonesia Nomor 6 Tahun 2014 Tentang Desa, Pub. L. No. 6 (2014).

Widjaja, H. (2003). Otonomi Desa Merupakan Otonomi Asli Bulat dan Utuh. PT. Raja Grafindo Persada. 